ISSN electrónico: 2172-9077

DOI: https://doi.org/10.14201/fjc202021149165

\title{
The Aesthetic and Discursive Presence of Television on Pedro Almodóvar's Cinema
}

\section{La presencia estética y discursiva de la televisión en el cine de Pedro Almodóvar}

Dra. Andoni ITURBE TOLOSA

Profesor adjunto. Universidad del País Vasco, EHU/UPV (España)

E-mail: andoni.iturbe@ehu.eus

(iD) https://orcid.org/0000-0002-1184-4634

Fecha de recepción del artículo: 13/05/2020

Fecha de aceptación definitiva: 21/07/2020

\begin{abstract}
RESUMEN
El artículo se centra en la presencia regular y constante de la televisión en las películas de Pedro Almodóvar. La televisión que, desde su primer largometraje (Pepi, Luci, Bom y otras chicas del montón, 1980) cobra una importancia relevante, será objeto de estudio desde el punto de vista discursivo y estético. La metodología consistirá en la revisión bibliográfica, el análisis de los guiones y los borradores, los dosieres de prensa y el análisis fílmico de las películas. Entre ellas, destaca Kika (1993) ya que la televisión forma parte destacada de su universo diegético. El artículo incide en dos resultados: el valor objetual de la pantalla televisiva y la posición del cuerpo frente a la televisión. Además, realizaremos un itinerario sobre los discursos puestos en práctica en torno a la televisión.
\end{abstract}

Palabras clave: Almodóvar; cine; televisión; Kika; intermedialidad, intertextualidad.

\begin{abstract}
This article is focused on the regular and constant presence of TV in Pedro Almodóvar's movies. Television, starting from Almodóvar's first film (Pepi, Luci, Bon y otras chicas del montón, 1980), acquires relevance that will be the object of study from a discursive and aesthetic point of view. The methodology consists in the bibliographic research and the analysis of the scripts, drafts, press kits and films. Kika (1993) is not the only film by Pedro Almodóvar where TV is implanted. Quite on the contrary, we shall see that the TV set has practically a constant presence in Almodóvar's oeuvre. As a result, it is important to mention the object value of the TV screen and the bodily position in front of the TV set. Furthermore, we will underline an itinerary on the discourses on television in the filmography of Almodóvar.
\end{abstract}

Key words: Almodóvar; cinema; TV; Kika; intermediality; intertextuality.

\section{Almodóvar and the tv screen: object value and bodily position}

Many analysts and film historians have pointed out the constant and regular presence of the TV screen in Almodóvar's oeuvre. From Cultural Studies, Television 
Studies have also served as a guide to evaluate the impact and the dialogue between cinema and TV motivated by the regularity of his production; familiarity or recognition (Julian-Smith, 2006, p. 151). Anyway, his television model has already been studied by Agustín Gómez Gómez (2012) at Fonseca journal. According to his analysis, the usual presence of the TV in Almodóvar's cinema acquires four distinctive forms: a realistic model, a critique on the so-called "trash TV" and, finally, an intertextual relation with a narrative purpose. Almodóvar's movies feed themselves in the first place on an intertextuality proceeding from the ecosystem of the culture of the masses, resulting in a daring hybridization of genres, with references of variegated mediatic genres contributing to an implicit comment on the representational conventions of traditional television and cinema (Gubern, 2005, p. 51). The movies of Almodóvar should also be studied with an original semiotic analysis. According to Seguin, the presence of the TV should be examined as a layer superimposed on the surface, a dissociation or even maybe an excrescence of the territory penetrating its borders (Seguin, 2009, p. 133). Transtextuality is one of the elements that characterizes the cinematographic work of Pedro Almodóvar (Poyato, 2012).

In recent years, different critical paradigms have returned to the filmography of Pedro Almodóvar: from the Theory of Polysystems (De la Torre Espinosa, 2017) to contact theory and haptic cinema (Zecchi, 2015) or intermediality. Or the recent essay of Sánchez Noriega (2018) in which he addresses the postmodern «aesthetics of passion» of Pedro Almodóvar.

Our main objective is to reassess the presence of television and television constructions from a new perspective: The Aesthetic and discursive presence of television on Pedro Almodovar's cinema. Our initial hypothesis suggests that the analysis of the way in which Pedro Almodóvar introduces the world of television and engages in dialogue with it may be productive. We will focus here on two aspects: the object value of the TV screen and the bodily position in front of the TV set. When looking at the contemporary art tendencies, we observe that the very reception and genuine meaning of the gaze, the act of watching itself, has changed. We shall start our analysis by considering the place of the TV set within the scene. Let us look now at how Almodóvar is positioning and relating the object of the TV screen in several of his movies.

At the end of the sixties, Pistolleto (1933, Biella-Italy) was hanging up his paintings just above floor level, in order to put the contemplative capacity of the spectator to the test. Let us look now at the position of the TV screen in Almodóvar's very first movie: Pepi, Luci, Bom y otras chicas del montón (1980).

Images 1. Pedro Almodóvar. Pepi, Luci, Bom y otras chicas del montón, 1980.
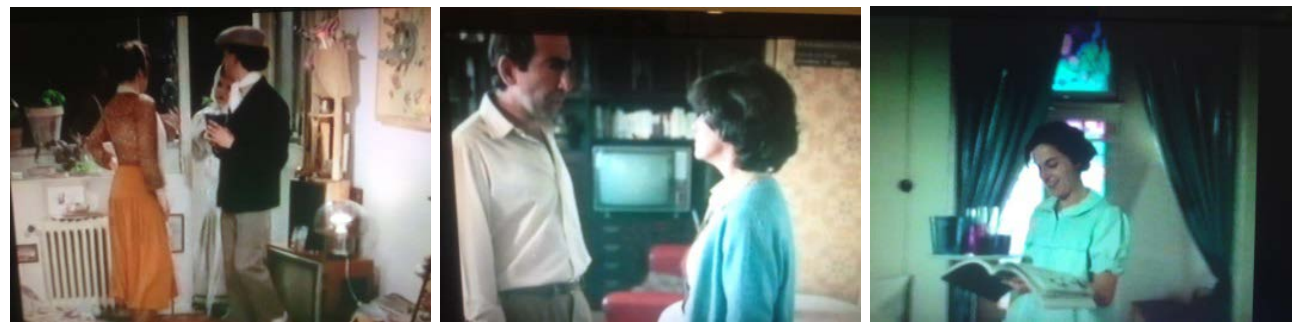

Source: screen shots (research purposes) 
In the screenshot on the left we get an insight into the room of Pepi (Carmen Maura). The television set is placed directly on the floor. In the screenshot in the middle we experience the domestic universe of Luci and her husband. Here the television screen appears in an intermediate position. At yet another moment in the film, namely in the scene where we are in the mad house of Bom, the TV is located at the highest point possible, in an unreachable position. So, we witness three main characters and three different positions of the TV set: three ways of seeing and acting in front of the television.

Let us also look at the mode of visualizing, watching, and shaping the TV set in Volver (2006):

Images 2. Pedro Almodóvar. Volver, 2006.
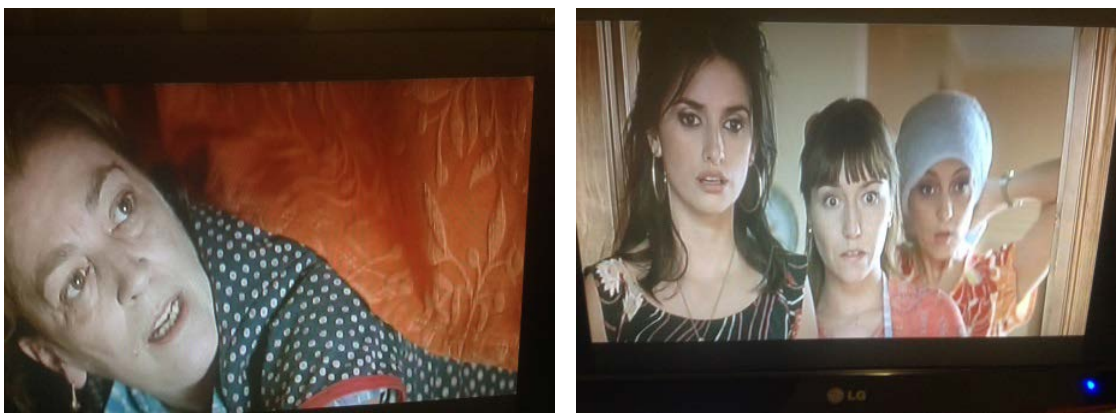

Source: screen shots (for research purposes)

In Volver's screenplay notes we read the following on sequence 91: ("De pie en la puerta de habitación, Sole, Raimunda y la clienta. Sentada, Paula. Y la abuela debajo de la cama» ${ }^{1}$.

The object-character of the TV set in the movie allows us to highlight its object-character in the way that artists like Nam June Paik (1932-2006) did, by exploring the discursive medium and manipulating the images to a degree in which they appear on screen in their presence as an object. At the sixties, video was an emerging discipline involving a new support and a new object: the TV set.

Images3. Nam June Paik and Pedro Almodóvar. Magnet TV, 1965; Tacones Lejanos (1991); Carne Trémula (1997)
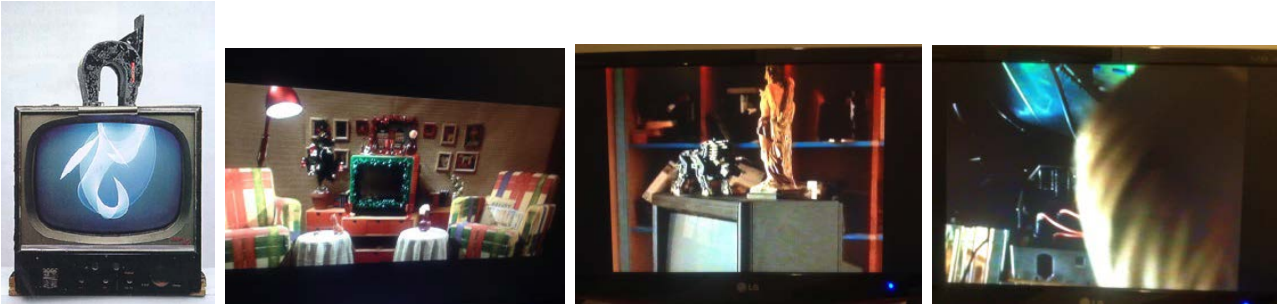

Source: screen shots (research purposes)

1. "Standing in the doorway of the room, Sole, Raimunda and her client. Sitting position, Paula. And the grandmother under the bed". 
On the left, we see an image of an artwork by Nam June Paik, entitled Magnet TV (1965). In it, the artist mobilizes the pixelated image towards more sophisticated or extra-televisual forms, with the double goal of objectifying and humanizing television in its dual nature as both object and image. In this artwork, the artist manages to open the television to attribute to it a more significant formal or decorative appearance. On the right, we see an image from Carne Trémula (1997) and next to that, another one from Tacones Lejanos (1991). They depict two constructions of the idea: the TV set is part of a decoration and at the same time it is embellished and even taken apart by the protagonist (Victoria Abril), since this is where she is hiding the weapon. From the sixties of the twentieth century on, video artists shifted their focus of attention and started to question the very televisual experience. In La ley del deseo (1987) and Tráiler para amantes de lo probibido (1985) the characters literally (and respectively) come to destroy a typing machine and a TV set. The first character's act as the result of frenzy, and the second one's act motivated by anger caused by the image constructed at the start of the movie.

We ought to signify another part of the screenplay of the film Carne Trémula, and more specifically, the following phrase: "You lay down like a guy to watch television" ${ }^{2}$ (Sancho to Clara). Clara: I didn't realize lying down on the couch was a thing exclusive to men. Sancho: Well yes, it is... Clara: I'm tired. ("Te tumbas como un tío para ver la tele» (Sancho a Clara). Clara: No sabía que tumbarse en el sofá fuera cosa de hombres. Sancho: Pues lo es.... Clara: Estoy cansada.).

\section{Images 4. Pedro Almodóvar. Carne Trémula (1997); Matador, 1986.}
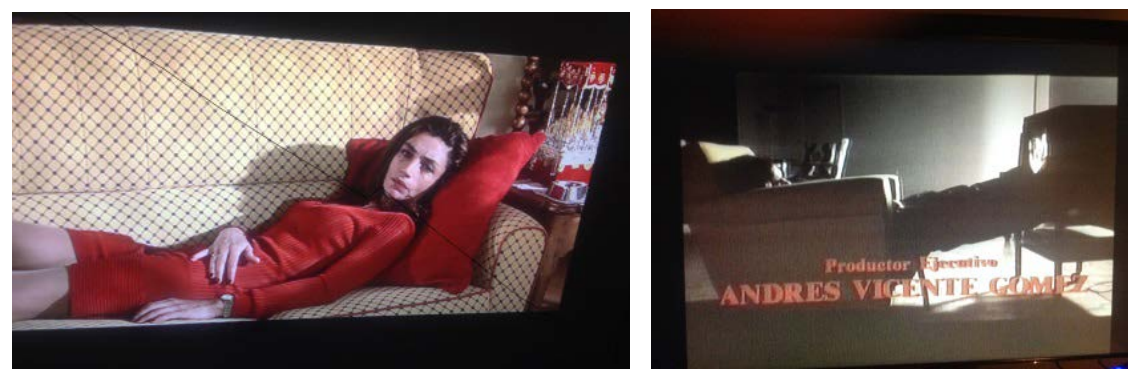

Source: screen shots (research purposes)

Ángela Molina, laying down watching TV. Watching her watch from and with her body. The screenshot on the right is the opening shot of Matador (1986); the

2. It is not the first nor the only time that Almodóvar deals with this topic. On page 8 of the screenplay of Volver we read: «Paula greets the father and reaches out for the phone, while laying down on the full length of the couch. The negligent pose of Paula is not very feminine. In the living room they are watching television» ("Paula le dice hola al padre y se lanza al teléfono, tumbándose cuan larga es en el sofá. La descuidada postura de Paula no es muy femenina. En la sala están viendo la televisión»).

3. "Clara maintains her horizontal position on the living room's sofa, exhausted in front of the television [...] Clara reaches for her glass without changing her position, left alone on the sofa, with her legs crossed. She takes a sip" ("Clara permanece tumbada en el sofá del salón, exhausta frente al televisor [...] Clara coge el vaso sin cambiar de postura, abandonada en el sofá, con las piernas separadas. Da un sorbo» (Almodóvar, 1997, p. 154). 
protagonist gets excited by watching television while the body emerges as a physical prolongation of the TV set.

The act of watching is being halted and justified before its objectual and significant presence. The case of Talk to her (Hable con ella: 2002) is a paradigmatic one.

Images 5. Pedro Almodóvar. Hable con ella, 2002.
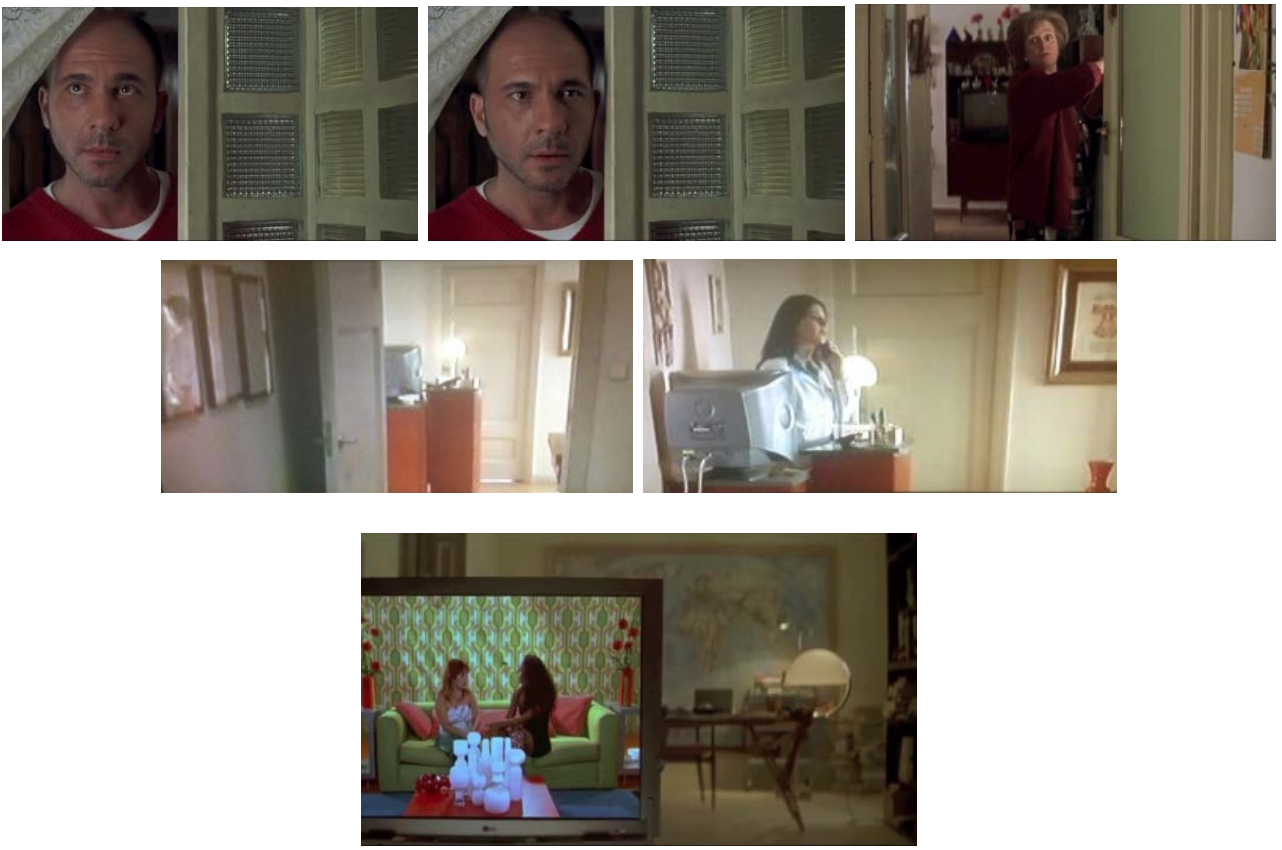

Source: screen shots (research purposes)

The character watches over the place and sees a television set in front of him: the TV set is located in a better position for him than for the house clerk who makes a comment on trash TV. The fourth and the fifth screenshot conform the idea of the objectual centrality of the television set in the reception of the psychiatrist. The last screenshot signifies the idea of trash TV to which the tenant alluded. We have a practical material that indicates a turned-off TV, or better yet, a television with its visual and acoustic signal forsaken, which in turn creates a mental representation that evokes the signified, namely the concept of trash TV (last image):

In Volver ${ }^{4}$ we already highlighted that the character-ghost (Carmen Maura) watches TV while sitting on the floor as is the case in Almodóvar's first movie; in Bad education (La mala educación: 2004) they watch television from the floor, although the size of the TV set is being distorted.

4. In Volver we find some remarkable screenplay notes that create metaphors on the suggestive power of television: flames that cross the threshold of the screen; flames equal to television (danger). "Their attention is being drawn by a new apparatus of television, turned on, never said better, literally aflame» («Les llama la atención un nuevo aparato de televisión, encendido, nunca mejor dicho, literalmente en llamas»; Almodóvar, 2006, p. 11 of the screenplay). And trash TV (telebasura), the same as drugs. 
Images 6. Pedro Almodóvar. Mala educación, 2004.
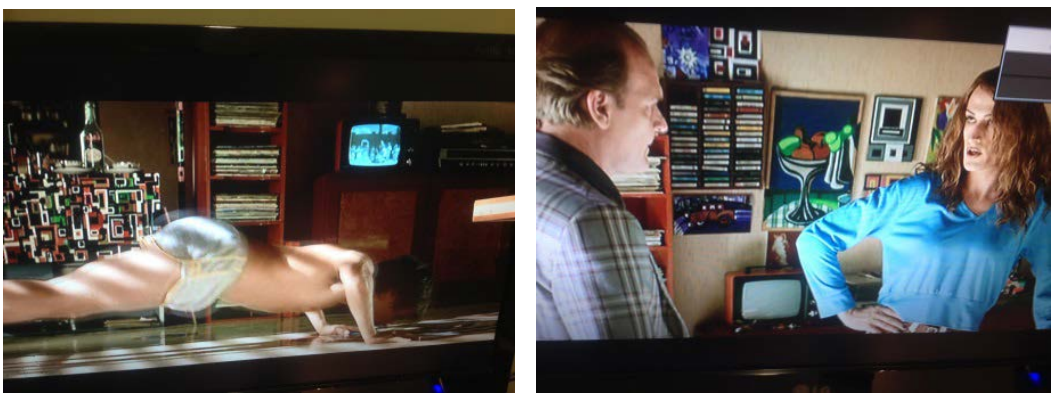

Source: screen shots (Research purpose)

Sequence 101 of the screenplay: «Sr. Berenguer le da papelinas (o mejor, dinero) a Ignacio, disimuladamente, mientras Juan mira al televisor, displicente (o hace gimnasia, en el cuarto de al lado, o juegan los tres al parchís, con la televisión directa5)». In the screenshot on the left, the television device appears with an amplified-size effect and with a more reduced-size effect in the image on the right.

It is not the first time that the trained eye (of the spectator) is summoned to notice a characteristic change like that.

Images 7. Pedro Almodóvar. Los abrazos rotos, 2009.
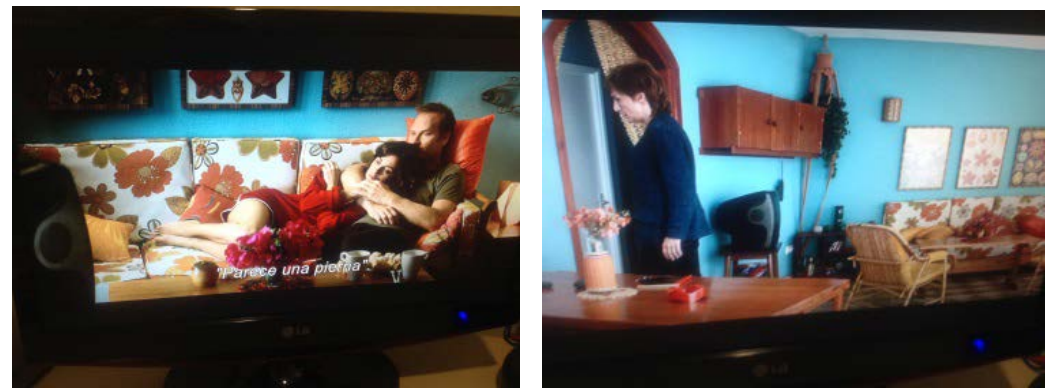

Source: screen shots (research purposes)

Screenshots of the portable TV set in Broken embraces (Los abrazos rotos: 2009). Another example of the portability of the device.

\section{Itinerary on the Discourses on TV in the Filmography of Almodóvar}

In Carne Trémula (1997) the director predicts the television of the nineties (practically of 1990): still weak because of the lack of competition (considering the screenplay notes where the director states that there were only two competing TV channels).

5. «Mr. Berenguer hands over the folded papers (or better, the money) to Ignacio, dissimulating, while Juan watches TV, indifferent (or he is working out in the adjacent room, or the three of them play Parcheesi with the TV turned on)". 
Three operations come together in Carne Trémula: passive body posture in front of the TV set and the radio, the decorative and functional elements of the television device ${ }^{6}$ and a shift into the private of the public news program.

Let us briefly take a closer look now, for instance, at the TV report on the victory of the Paralympics' basketball team. How does the text realize this shift? On the one hand, the screenplay grants a close-up validity to the informative event:

"Off Locutor: La selección española ganó por 56-52 (Nota: la acción relatada por el locutor se ve en primer plano, en el televisor ${ }^{7}$ )».

Images 8. Pedro Almodóvar. Carne Trémula, 1997.
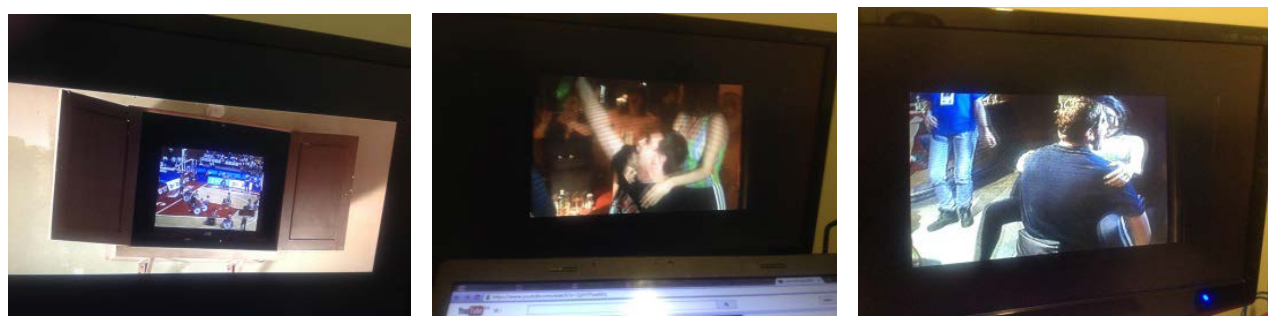

Source: screen shots (research purposes)

In Carne Trémula, as Agustín Gómez (2012) observes, fiction is being relocated by means of the televisual medium, towards a medium that is recognized as being close to a real referent ${ }^{8}$. Nonetheless, withstanding the screenplay note (cf. supra) in the end we see the mentioned news program enunciated in a general wide shot. From that moment on, the shift of the information towards the private sphere is gaining strength, this being evident in both the voice-over and in the words enunciated: "Amongst the public the decisive basket is celebrated by an exceptional female spectator» ("Entre el público una espectadora de excepción celebra la canasta decisiva»). From then on, both voice-over and enunciation shift towards private territories: dancing, discotheques... The screenplay notes suggest that «the absence of real sound [we are listening to a song performed by Albert Pla] attributes to the images a patina of irrationality» («la ausencia de sonido real proporciona a las imágenes una pátina de irrealidad»).

The comment notes of Carne trémula's screenplay point out that the televisual and radiophonic devices create a bond with the characters: (EEl perfil de la cabeza de corcho (habla de la cómoda) está orientado hacia la radio" $»$; screenplay edited by Plaza Janés (Almodóvar, 1997, p. 25). We are warned about the presence of the TV set through the notes of the screenplay (Almodóvar, 1997, p. 60):

6. The screenplay notes highlight the fact that the television device that is contained in a box does not obey to a decorative decision.

7. "Commentator voice-over: The Spanish team have defeated ... (Note: the commented event is depicted in close-up on the TV set)".

8. In "Andrea Caracortada y el modelo de televisión" (Gómez, 2010) we read that television is converted into a way of articulating the narration, in such a manner that the events are visualized from inside the prison, apart from adding a sense of verisimilitude to the story.

9. "The profile of the cork head (talking about the commode) is oriented towards the radio". 
Un leve murmullo indica que la televisión está puesta [...] en un rincón está el televisor. Como no puede quedarse quieta, Elena zapea continuamente. En el 90 [Almodóvar habla del año 90] había solo dos cadenas, o sea que el zapping no da para mucho, pero es una buena forma de machacarte los nervios ${ }^{10}$.

In sequence 34 Almodóvar underlines the fascination for the television screen by Víctor, who "absorbedly watches the movie on TV" ("mira absorto la película de la televisión", Almodóvar, 1997, p. 77). Later on, we will know that the only object of luxury in his miserable house will be a television screen amongst «disposable materials, pure Arte Povera" ("materiales de desecho, puro arte povera" (Almodóvar, 1997, p.130).

¿Qué he hecho yo para merecer esto!! (1984) is another movie where constant references to the TV set appear insistently in the screenplay notes (Almodóvar, 1984, p. 18). ("Enchufa el televisor en color. No se ve y provoca un ruido infernal. Antonio trata de arreglarlo a base de golpes. Consigue que la imagen se quede quieta pero el sonido sigue siendo insufrible. El programa, por otra parte, es repugnante, sobre todo si se piensa que se emite durante la cena ${ }^{11}$ » (Almodóvar, 1984, p. 16). The sound of the television is persistent as we can appreciate from the references to advertisements in the screenplay: "Meanwhile, on the TV screen, one of the many publicity advertisements» («mientras, en la televisión, uno de tantos anuncios»).

The leap from the eighties to the nineties brought with it an intense debate on the role and future of television in Spanish society. In this regard the following screenplay notes of Almodóvar's movie from 1982, entitled Entre Tinieblas, are of special interest to us: "He explains it to him in an informative-exhibitionist manner" (Le explica en plan informativo-exhibicionista", Almodóvar, 1982, p. 13).

In Mujeres al borde de un ataque de nervios (1988) Doña Paquita, the mother of Pedro Almodóvar, was still reading without the help of the auto-cue or, to put it in other words, she held up the craftsmanship of televisual information reading the news in the news program.

In the first screenshot we see the television set of the house of Pepa (Carmen Maura), who, accommodated in the sofa in the same way as Clara (Ángela Molina) in Carne Trémula, watches the advertisement of Ecce Omo. It is the first time that the televisual images take a real referent like Telediario (TVE, Spanish Public Television). In the second screenshot on top we see an iconic image of this informative program, and on the right, we enter the house of Marina Barranco, who has the same TV set model (Sony) as Pepa. The television device therefore unites two female spectators in an alternating montage through the virtual reference of the Piruli (TVE). The relationship between the public space (she works in the world of advertising and television) and the private one (the same world of advertising and television in which she met her lover) is tense.

10. "A light murmur indicates that the TV is switched on [...] the TV screen is set in a corner. As she cannot remain still doing nothing, Elena is switching channels all the time. In the year 1990 [Almodóvar talks about the year 1990] there were only two channels, so there was not a lot of switching to do, but it is a good way of wrecking your nerves".

11. "The colour TV switches on. Nothing appears on screen and an infernal noise is heard. Antonio tries to fix the TV by hitting it. He succeeds in making the image remain steady, but the noise is still unbearable. The programme, on the other hand, is repulsive, particularly all because is being broadcast during supper". 
Images 9. Pedro Almodóvar. Mujeres al borde de un ataque de nervios, 1988
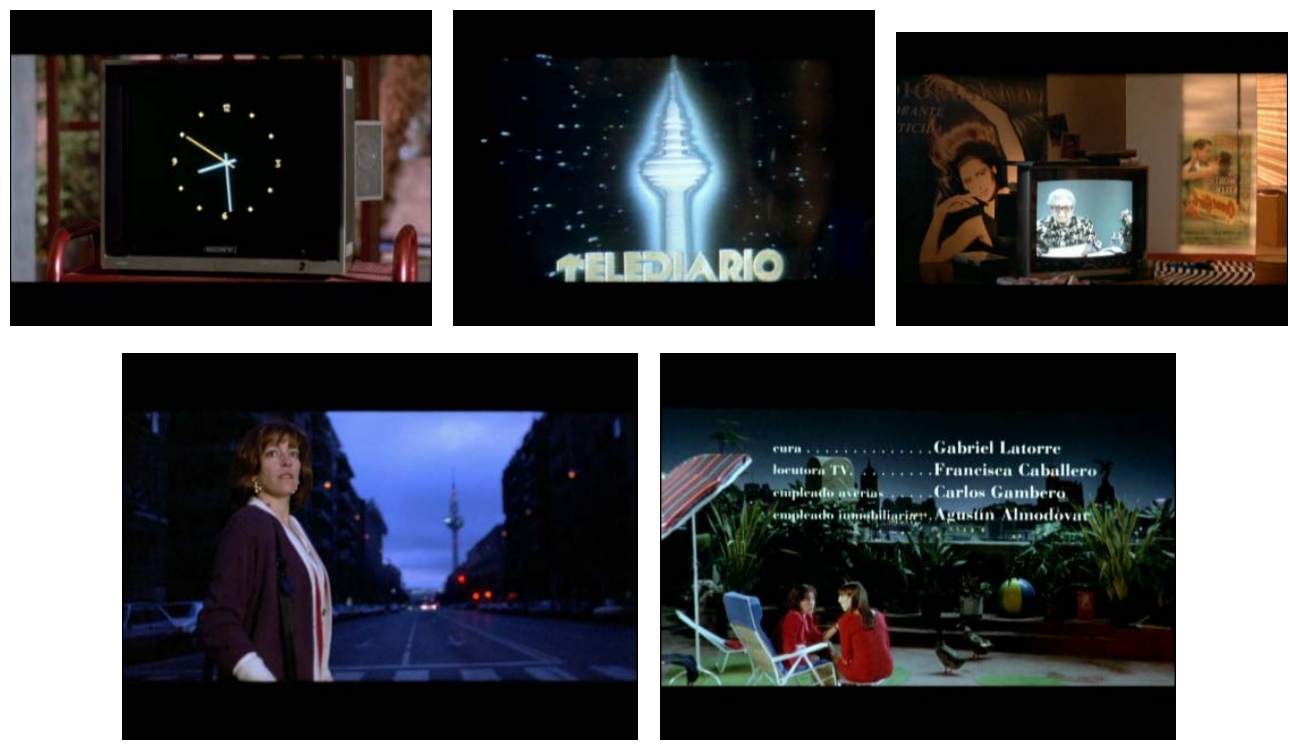

Source: screen shots (research purposes)

\subsection{Mirror-Melodrama and TV}

Douglas Sirk, the referent of American melodrama, deploys the speculative ostentation of television to extinguish the sentimental expectations of the female protagonist in the film All that heaven allows (1955), in a similar way as Almodóvar is converting the mirror-television into the loudspeaker-mirror of the calamities of his characters.

Images 10. Douglas Sirk and Pedro Almodóvar. All that the heavens allows", 1955 and La flor de mi secreto, 2006.
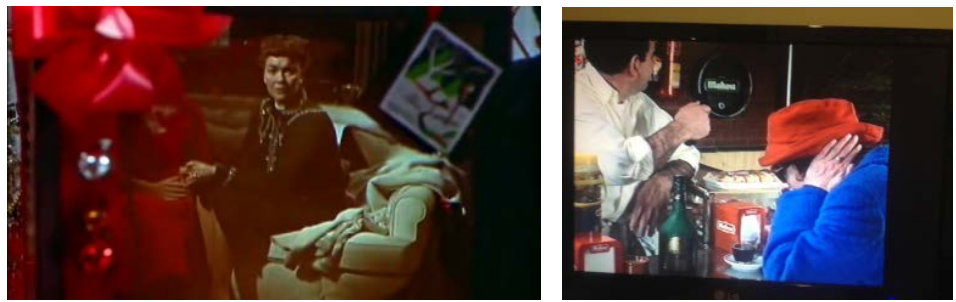

Source: screen shots (research purposes)

Melodrama is one of the genres that are a well-known territory to Almodóvar. In the screenshot on the left we see Cary Scott (Jane Wyman), a mature, worn-out woman, seeing her own reflection on a TV screen on which she projects the feeling of not being an attractive woman anymore. Sirk converts hereby the TV object in a poisoned present, in the same way as in the scene where the female protagonist of $L a$ 
flor de mi secreto covers her ears to the heartbreaking voice of Chavela Vargas ${ }^{12}$ on the TV set that makes her remember her condition. In the screenplay published by Círculo de Lectores her malaise is emphasized: (Leo se vuelve hacia el televisor. Chavela transmite, con voz rota y amaestrada por años de infierno, todo el dolor acumulado por Leo (...) Chavela ha abierto dentro de Leo, sin avisar, las compuertas de un verdadero pantano de amargura por Leo ${ }^{13}$; ; sequence 54, Almodóvar, 1994, p. 115). The notes in the screenplay once more emphasize the presence of the TV set: (\$Secuencia 26. Casa de Rosa. Entran en el saloncito, dominado por una mesa rectangular de cristal, un gran aparador que incluye el televisor, y un sofá semicircular ${ }^{14}$ » (Almodóvar, 1994, p. 49). The screenplay notes are not about the kitsch ostentation anymore, but on the ugliness of the objects. "In the house you can see some of the personal artworks of the husband. Very ugly ones» ("En la casa pueden verse algunas de las obras personales del marido. Todo muy feo").

The duration of the scene and its arrangement and montage prove how the use of a bolero, which occupies practically the entire sequence, has a clearly narrative functionality that transcends the purely expressive illustration (De la Torres Espinosa, 2017, p. 12).

Almodóvar's construction of television definitely originated in a revealing image that presents the small screen as an artefact of aggression and domestication of desires. The reflecting screen is where the mundane passion of the female protagonist, in front of an in-vogue consumer good, gets (de)motivated. The mannerism of Sirk confronts the gaze that transmutes towards the objectification, and the act of embodying the perception. Sirkanian mirrors are metaphors of loneliness, being extended by means of the television screen that reflects the loneliness oppressing Leo (Marisa Paredes).

\section{The Construction of the Televisual Image in Kika}

Kika is the first movie that is exclusivity dedicated to the construction of a TV programme: a programme which is called Lo peor del dia. The presence of this reality show is tangible throughout the movie. For this reason, it deserves a special mention. Kika is a conceptual movie (Zunzunegui, 1999, p. 938).

We have identified, on the one hand, the draft entitled Collage; and, on the other hand, we have focused on the seventh version of the screenplay (this draft was deposited under the final name of the movie, Kika). Apart from these consultations of deposited material a formal request was also submitted to the film company El Deseo to obtain the final list of the dialogues.

12. Fredéric Strauss (2001) talks about the image of Chavela, on television, singing about abandonment. In one of these conversations, Almodóvar describes what Leo feels as something similar to a hallucination (Almodóvar, 2001, p. 140). It is also interesting to find out that Almodóvar considers melodrama as the genre that has damaged television the most (Strauss, 2001, p. 107).

13. "Leo turns towards the TV. Chavela transmits, with trained and broken voice after living in a hell for many years, all the pain accumulated by Leo (...) Chavela has, without any warning, opened up inside Leo the doors of an immense lake of bitterness for herself,.

14. "Sequence 26. Rosa's house. They enter in the small living room, dominated by a rectangular crystal table, a big piece of furniture that contains also the TV screen, and a semi-circular sofa». 
The publication Antología critica del cine español (re)valorised Kika to the point of highlighting its contribution beyond its styling. It shows in the text an unstable combination of naturalism and abstraction, which according to the author permits an awareness of the spirit of the time (Zunzunegui, Antologia del cine español, 1999, p. 939). It is structured around a new genre: «Kika is structured entirely around the new genre of reality TV» (Julian Smith, 2006, p. 147).

\subsection{Press Kit and Epitext}

From the press kit we can also extract some clarifying conclusions on the construction of the televisual image and how the very own author himself interprets the projection of his creative process:

a) Almodóvar criticizes the residual role of the spectators in TV programmes, and the very artifice of language: ("Tampoco Andrea se relaciona con sus interlocutores, es decir, con el público de su programa. Se supone que es un programa en directo, pero lo hace ella sola; "público atrezzo»; "risas enlatadas ${ }^{15}$ »).

b) Definition of the role of Andrea Caracortada ("director and journalist»; «directora y repor-tera") and her obsession with the spectator ratings: "Andrea is lulled to sleep by the Ecotel ratings» ("Andrea duerme arrullada por los índices de Ecotel»).

c) A manifested hate towards that which represents the universe of television: ( «Siento un rechazo natural hacia los políticos y los presentadores de televisión». "Andrea siempre está en los lugares donde ocurren los hechos más sensacionalistas». "Casi nunca veo la televisión ${ }^{16}$ »).

d) The press kit is an extension of the graphic design of the film poster and a sample of a collage in all its manifestations.

e) Not one reference to Doña Paquita, his mother, moderator of Hay que leer más.

f) Eulogy on the (in)communication by means of the explicit mentioning of the professions: moderator (Andrea) and writer (Nicholas).

\subsection{Kika and the Kitsch Objectification}

The screenplay note of his first film denotes this conscience of kitsch art, the attraction it has as an aesthetic category and the effect of objects. Which kind of kitsch effect is caused by the television device in Kika? Two images bring us once again towards the TV as an object. The television is part of a stylized room where the objects remain unaltered through the means of a prevailing unity.

15. Andrea does not interact with her interlocutors either. The programme is supposed to be broadcast live, but she runs it on her own; "prop audience»; "canned laughs".

16. "I feel an innate repulsion towards politicians and TV moderators". "Andrea can always be found on the places where the most sensationalist things occur». "I almost never watch TV». 
Images 11. Pedro Almodóvar. Kika, 1993.
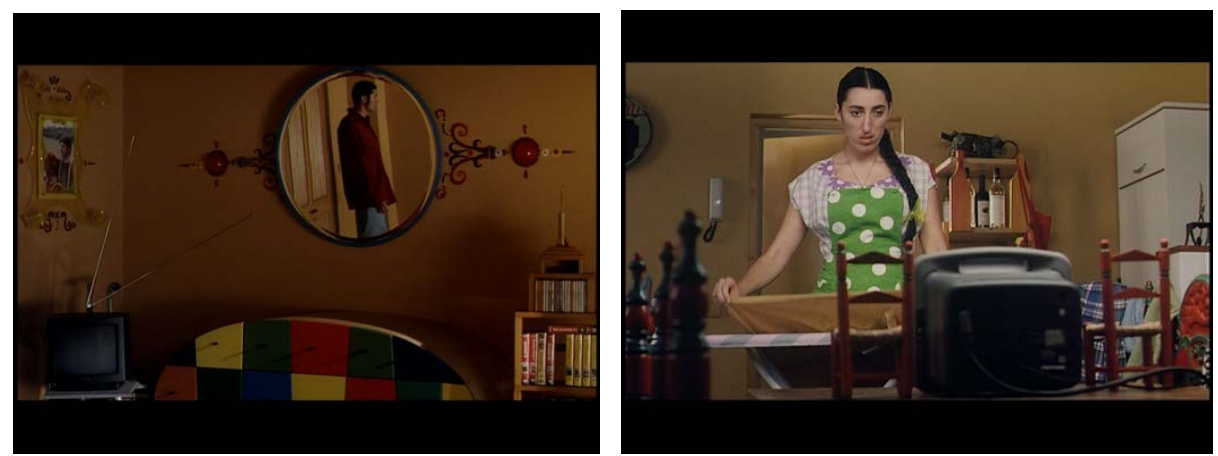

Source: screen shots (research purposes)

On the left, an image of the TV set with its two prominent antennas that create a sensation of unity and symmetry: two objectual spaces with antennas and a book tower-skyscraper. On the right, there is an image of the television in the kitchen of Juana, the housemaid. It is from the 90s on that the increase in size of the LCD screens takes off. Furthermore, it is interesting to notice, one more, the portability (or lack of continuity?) of the TV set, present in both positions in the kitchen (the screenplay notes indicate that in both cases we see the kitchen).

\section{Images 12. Pedro Almodóvar, Kika, 1993.}

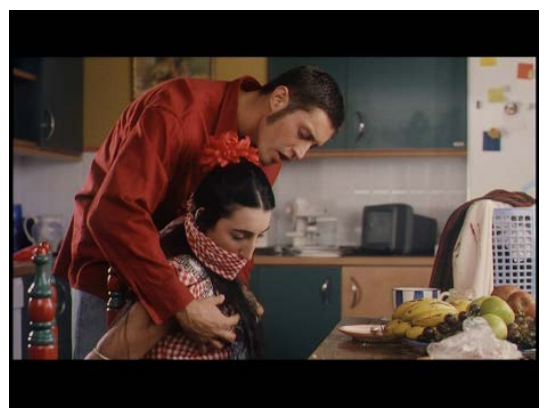

Source: screen shots (research purposes)

There is a change in the characteristics of the prop, or of the objectual aesthetics of the television set.

In Kika (1993), several types of connections focus on objects, namely the following:

- the television device in relation to the rest of the objects in the house.

- the relationship of the objects that identify the protagonists.

- the relationship of the objects that help the characters to identify each other.

- the relationship of the human bodies with the television set. 
Images 13. Pedro Almódovar. Kika, 1993.

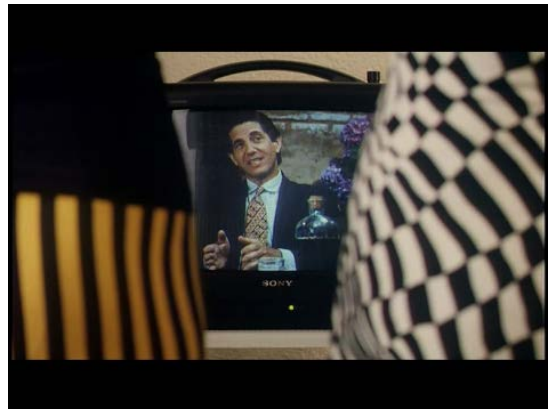

Source: screen shots (research purposes)

Kika and her friend Amparo, both positioned standing in front of the screen, are watching the interview programme moderated by Doña Paquita. We see Amparo's dress (on the right), in black and white (the same colors of the conceptual decoration thought of initially by Almodóvar), and the outfit of Kika (on the left).

\subsection{Kika: Referential and Virtual TV}

The screenplay notes on Lo peor del día are quite straightforward: ("Se trata de un programa típicamente sensacionalista, ilustrado por imágenes reales de los acontecimientos más espeluznantes del día; por supuesto, no hay límite ideológico, moral o estético ${ }^{17}$ ", (Almodóvar, 1993, p. 46).

Is this, therefore, how the very own Almodóvar ("when I wrote the screenplay of Kika reality shows still did not exist in Spain" (Strauss, 2001, p. 118) brings the prediction or the announcement of a genre, the reality show, that didn't exist in the panorama of Spanish television at the time?

Was the programme of Lo peor del dia already a misfit in the televisual universe, at least in Spain? We should add here a third incidence of the construction of the televisual image: the idea that anybody could become a TV moderator (as a reference to the appearance of his mother as a moderator $)^{18}$. The construction is based therefore on anticipation, and the dichotomy familiarity-unrecognizability: "She can have this appearance, or any other, as long as she appears unrecognizable»; "Puede tener este look, o cualquier otro, lo importante es que resulte irreconocible» (screenplay notes on Ana Caracortada's character). His mother, Doña Paquita, on the other hand, is the example of familiarity par excellence.

Iturbe (2016) analyzed the way in which Pedro Almodóvar was based on the Spanish television content of the 90s. On the one hand, he was inspired by one of the references of sensationalism of the 90s (the television treatment of the crimes of Alcasser) and, on the other hand, the references to Eurovision.

17. "It concerns a typical sensationalist programme illustrated by the real images of the most hair-raising events of the day; obviously, there are no ideological, moral or aesthetic limits».

18. Almodóvar is referring here to the TV program of Carmen Sevilla (Spain), who had already retired from cinema 25 years earlier and who became famous thanks to the broadcast in which she was making mistakes all the time (Strauss, 2001, p. 121). 
(«Por un extremo del escenario aparece una pobre mujer de 50 años vestida para la ocasión. Tomar como referencia a la madre de Antonio Anglés ${ }^{19}$, note of the screenplay).

Images 14. Pedro Almodóvar. Kika, 1993.
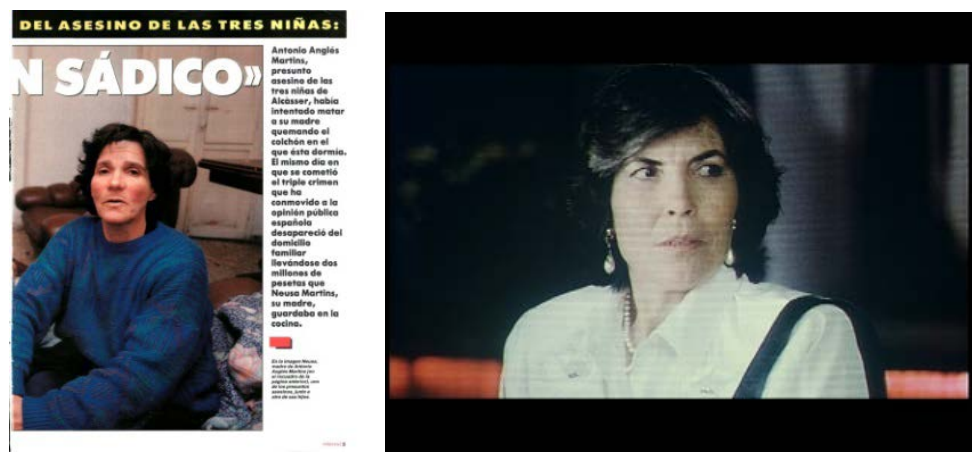

Source: screen shot and press clip (research purposes)

On the left we find a press clip of the mother of Antonio Anglés. On the right we see a screenshot from Kika, of the character of the mother of Joaquín "El portugués». The murderer's mother ${ }^{20}$ visits the TV programme Lo peor del dia. «The mother of the assassin was the doorwoman of the office building where we worked (...) The amount of small essential interventions in my movie style, interpreted by casual people, is enormous» (Almodóvar ${ }^{21}, 2015$ ).

The decade of the nineties comes to us altered by, amongst other presences and absences, the media coverage of the assassination of three girls from Alcasser. Lorenzo Díaz upholds that in the night of Alcasser a lot of excesses were committed, and not only on the part of Nieves Herrero, who was converted into an easy scapegoat of all the wrongdoings (Díaz, 1999, p. 75). Díaz (ibid.) continues stating that, with this inauspicious night of our television broadcast (both public and private ones), we witnessed how the limits that televisual ethics impose were crossed with regard to the commercialization of the feelings and dignity of the individuals.

\subsection{A TYPE OF REALITY SHOW CALLED STRINGER}

Antequera describes Victoria Abril as a violent creature that is fascinated by and dependent on this generation of reality shows called stringers. The so-called stringers are a televisual subgenre that consisted in the videos that were provided, in exchange for money, by the average North-American citizens (Antequera, 2003, p. 12), the latter

19. "A poor woman in her fifties appears, dressed for the occasion, entering from one end of the TV stage. Take as a reference the mother of Antonio Anglés».

20. Pepa, from the film Mujeres al borde de un ataque de nervios, is a profesional dubbing actress and publicity actress, famous for her role as "the murderer's mother» in a TV commercial: "Taxi driver 1: You are from TV, right? The murderer's mother. Pepa: Yes. Taxi driver 1: Do you mind signing an autograph for my wife?» (Taxista 1: Usted es de la tele, ¿verdad? La madre del asesino. Pepa: Sí. Taxista 1. ¿Le importaría firmarme un autógrafo para mi mujer?»: page 35 of the screenplay). The representation of the mother is a pop device that was already established earlier by Iván Zulueta (see the advertisement of the mother of The Beatles).

21. Published and consulted on October 31st, 2015, El País. 
being converted into active spectators, capable of reverberating the program and broadcasting that which they filmed themselves, this generally consisting in violent events. Almodóvar insists that a North-American TV program retransmitting trials was a great incentive for him (Strauss, 2001, p.118): («Poco a poco he ido comprendiendo que las imágenes en vídeo se iban a convertir en un mercado enorme para la televisión ${ }^{22}$ ). As we already mentioned, Almodóvar stresses the fact that when he wrote the screenplay, reality shows did not exist in Spain.

At the beginning of the nineties the term "reality show» started to create meanings that were still under construction. Both specialized magazines and daily newspapers recurred to the term that still created a certain curiosity due to its novelty and alteration of meanings ${ }^{23}$.

\section{Conclusions}

The relationship between cinema and television has been especially close in Pedro Almodóvar's cinema. Therefore, after scrutinizing the entire discursive and aesthetic itinerary made around television, we can emphasize the importance that the television universe acquires in his filmography. The analysis of the scripts and film analysis, with an emphasis on the aesthetic and discursive aspects of the presence of television, have been revealing.

About the objectives set out in the article, it would be possible to confirm the effectiveness of the analysis performed. The aesthetic and the discursive aspects have both been highlighted. We have confirmed the importance of the object and the bodily position in front of the television, as well as the discursive itineraries present in the movies. In this sense, in the case of Pedro Almodovar's filmography the object of the TV set is not a mere prop and decorative element, but an active aesthetic element that inspires and engages in dialogue with the space, the characters and the bodies. Thus, it would be possible to conclude its double value: as the object value of the TV screen and the bodily position in front of the TV set.

In addition, it is worth remarking a note from the script of Carne Trémula, which intervenes in the aesthetic role of television in relation to other aesthetic or artistic practices. Later, we will find out that the only object of luxury in the miserable house will be a TV screen, positioned alongside "waste materials, pure arte povera" (materiales de desecho, puro arte povera" (Almodóvar, 1997, p. 130). About Kika, Almodóvar also suggests that the paintings are the immediate metaphor of the eye of television (interview with Strauss, 2001, p. 126). Kika was the first Spanish film that built a fictional program that had no place on the Spanish television network (Iturbe, 2016).

Likewise, the presence of television articulates its own discourse on the informative, sensationalist or speculative function of television, widely present in Pedro

22. «Little by little I came to understand that these video-images would become a huge market for television".

23. The news item of the $23^{\text {rd }}$ of August 1993, in the newspaper El País entitled «Constantino Romero presentará un reality show en TVE a partir de otoño" is peculiar for its content. The program being announced here was called Valor y Coraje (1994), and this TV program would deserve a more detailed analysis on the nature of the reconstructions, dramatizations, or the docudrama. 
Almodóvar's filmography and in line with the evolution and perception of television in Spain.

Nevertheless, if at first, we took for granted that television has a regular and constant presence in Pedro Almodóvar's filmography, it should be noted that its presence has been languishing in the latest productions (Pain and Glory, 2019; Julieta, 2016; Los amantes pasajeros, 2013).

Finally, it is worth reiterating that the ties between cinema and television have been especially striking in Spanish cinema. Undoubtedly, many scholars have focused on the analysis of television presence in the case of some iconic directors such as Almodóvar or José Luis Sáenz de Heredia (Iturbe, 2020) contributing different methodologies: cultural studies (Paul Julian Smith); or recent works on the History of the Social Mass Media (Lucía Tello, Fernando Cabezudo, for example), or semiotics.

The presence of television in certain films is generally due to the influence of television on the social imagery as well as the individual influence on many directors; the strong historical interdependence between the two industries in terms of financing or promotion (another aspect that would have to be examined in further studies); or due to the emergence, evolution and competition of the two industries since television began to establish itself in Spain at the end of the 60s.

A broader analysis would allow us to delve into a more complex substratum in terms of the ties between cinema and television through a framework that has not yet been fully addressed in the Spanish academic sphere: the history of docudrama in Spain.

\section{Bibliography}

AA.VV. (1999). Antología crítica del cine español. Madrid: Cátedra.

Almodóvar, P. (1997). Carne Trémula. Madrid: Plaza y Janes.

Antequera, S. D. (2003) Estallidos de emoción pura. In Pedro Almodóvar. Las Palmas de Gran Canaria: Cuadernos de la filmoteca canaria.

De la Torre Espinosa, M. (2017). Nuevos paradigmas críticos para abordar la teatralidad en el cine de Pedro Almodóvar. Fotocinema. Revista científica de cine y fotografía, 14,111-132.

Díaz, L. (1999). Informe sobre la televisión en España. La década abominable. Barcelona: Ediciones Grupo Zeta. Crónica actual.

Gómez Gómez, A. (2010). «Andrea Caracortada y el modelo de televisión en Pedro Almodóvar». In: La Comunicación Social, en estado crítico. Entre el mercado y la comunicación para la libertad: actas del II Congreso Internacional Latina de Comunicación Social.

Gómez, A. (2012). El modelo de televisión en el cine de Pedro Almodóvar. Fonseca, Journal of Communication, 4, pp. 60-81.

Gubern, R. (2005). Las matrices culturales de la obra de Pedro Almodóvar. In: Almodóvar. El cine como pasión. Actas del Congreso Internacional de Pedro Almodóvar de 2003. Cuenca: Ediciones de Castilla-La Mancha.

Iturbe, A. (2016). Kika, de Pedro Almodóvar y los crímenes de Alcasser. In: L. Esteban; C. J. Almuiña Fernández (dir.), R. Martín de la Guardia (dir.), J. Vidal Pelaz López (dir.), Sensacionalismo y amarillismo en la historia de la comunicación. Madrid: Fragua.

Iturbe, A. (2017). Imaginario catastrofista en REC. Bajo el yugo del discurso televisivo. Comunicación y Medios, 36, 70-80.

Iturbe, A. (2016). Cine y televisión: construcciones televisivas en el universo fílmico español. Retrieved from http://addi.ehu.es/.../10810/18393/1/TESIS_ITURBE_TOLOSA_ANDONI.pdf 
Iturbe, A. (2020). Historias de la television, una película al servicio de la television. Aposta, 85, 148-160 http://apostadigital.com/revistav3/hemeroteca/aiturbe.pdf

Poyato, P. (2012). Referencias intertextuales de Carne Trémula (Almodóvar, 2017). Zer, vol. 12, núm 32, 121-139.

Sánchez Noriega, J.L. (2017). Universo Almodóvar. Estética de la pasión en un cineasta posmoderno. Madrid: Alianza editorial.

Seguin, J-C. (2009). Pedro Almodóvar o la deriva de los cuerpos. Murcia: Filmoteca Regional. Francisco Rabal.

Smith, P. J. (2006). Television in Spain. New York: Támesis.

Strauss, F. (2001). Conversaciones con Pedro Almodóvar. Madrid: Ediciones Akal.

Zecchi, B. (2015). El cine de Pedro Almodóvar: de óptico a háptico. Área abierta, 15, Monográfico: Estudios sobre masculinidades, LGBTIQ y cultura audiovisual.

\section{Scripts consulted}

- Carne Trémula.

- Collage. 7 th draft.

- Hable con ella.

$-K i k a /$ th vertion.

- Kika. Dialogue List. Courtesy of El Deseo.

- Entre Trinieblas.

- La flor de mi secreto.

- La mala educación.

- Pepi, Luci, Bom y otras chicas de montón. Legal deposit 28/11/1981. 
